Article

\title{
Strategies to Combat Mycosphaerella Leaf Disease in Eucalyptus globulus Plantations in Northern Spain
}

\author{
Severiano Pérez ${ }^{1, *}$, Carlos Renedo ${ }^{1}$, Alfredo Ortiz ${ }^{1}$, Felix Ortiz ${ }^{1}$ and Carlos Tejedor ${ }^{2}$ \\ 1 Faculty of Industrial and Telecommunications Engineering, Electrical and Energy Engineering Department, \\ University of Cantabria, Avenida de Los Castros, Santander 39005, Spain; renedoc@unican.es (C.R.); \\ ortizfa@unican.es (A.O.); ortizff@unican.es (F.O.) \\ 2 Bosques 2000 S.L. Grupo Sniace, Ganzo, Torrelavega 39300, Spain; bosques2000@sniace.com \\ * Correspondence: perezrs@unican.es; Tel.: +34-942-201-344
}

Academic Editors: Reynaldo Campos Santana and Eric J. Jokela

Received: 30 May 2016; Accepted: 18 August 2016; Published: 29 August 2016

\begin{abstract}
Eucalyptus globulus is widely planted in temperate regions to produce pulp for its high performance but few studies of the impact of Mycosphaerella Leaf Disease (MLD) have been documented. This study aimed to explore and provide knowledge on disease in the management of young Eucalyptus globulus stands in the north of Spain. The influences of subspecies, cloning, and fertilization on the degree of severity of the disease were analyzed. The study was conducted with different material plants of Eucalyptus globulus, of Australian origin, from other sources, open-pollinated families, clones, and families of controlled pollination. Each series tested different vegetal material, except for a number of control codes that were used as reference samples for MLD evaluation. Severity, height at which foliage changes from juvenile to adult, total height, and volume were all measured. There were significant correlations in the average MLD severity of families and provenances obtained from the different trials. ANOVA revealed important differences between subspecies of E. globulus. A correlation was found between the percentage of adult leaf and the severity. There were differences in the impact of MLD between plant material non-selected and selected by its tolerance $(p<0.0001)$. There was a significant effect on the severity between mature cuttings and families from seed non-selected in their tolerance to MLD. Their tolerance was lower than that achieved from seed selected by its tolerance to MLD. Genetic selection was shown as the best strategy since there are individuals exceptionally tolerant to MLD.
\end{abstract}

Keywords: pollination; clone; foliage; fertilization; severity; Crown Damage Index

\section{Introduction}

The forestry sector in Northern Spain and Northern Portugal is based on species belonging to the genera Pinus L., Quercus, Fagus L., and Eucalyptus L'Hér. The latter genus, with over 600 species, mostly from Australia, has undergone a spectacular development over the last 50 years [1]. Eucalyptus globulus Labill. is the main hardwood species grown in pulpwood plantations in temperate regions of the World [2-5]. In Cantabria (Northern Spain), the bioclimatic and geographical characteristics are optimal for the development of this forest species.

Eucalyptus globulus was introduced into Northern Spain and Portugal in 1880 [6]. Development and improvement of this species began in the 1940s with the establishment of the Sniace group. This company, an industrial chemicals group, owns more than 1500 ha and over 25,000 ha in consortia, all of them used for the cultivation of E. globulus. Bosques 2000 S.L. belongs to this industrial group and deals with the task of research and forest management.

Eucalyptus globulus is clearly better than native species in terms of wood produced and pulp yield [7-9]. There are alternative Eucalyptus species for cooler regions such as E. nitens H. Deane \& 
Maiden, but its pulp performance is much lower [10]. This species has proved itself to be highly adaptable to the climatic and soil conditions of the region, with average growth around 20 cubic meters per hectare per year. Regeneration is by coppice, with successful results found even in four rotations.

The genus Eucalyptus is affected by a large number of fungal leaf diseases [11], although Mycosphaerella leaf disease (MLD), which includes species within Mycospaherella Johanson and Teratosphaeria Syd. \& P. Syd. [12], is seen as one of the most important [13-15]. Infection of leaves appears when the acospores germinating on the leaf surface produce germ tubes which enter the leaf via stomata [16]. MLD is the major biotic limitation for development of this species in this region.

Over the past fifteen years, this disease has caused extensive defoliation to E. globulus plantations in Cantabria, resulting in a marked growth reduction, stem deformation and, in combination with frost, tree mortality. The disease affects over 41,000 ha in Cantabria and bordering regions, including Asturias and the Basque Country, accounting for an affected area in Northern Spain of approximately 200,000 ha. World-wide, this problem affects countries such as Australia, New Zealand, Chile, Spain, South Africa, Uruguay, and Portugal [17-21].

In the scientific literature on the subject there are studies that identify the species of the genus Mycosphaerella affecting Eucalyptus [22-26]. At this point, it must be said that in Northern Spain the species Mycosphaerella nubilosa (Cooke) Hansford, Mycosphaerella marksii Carnegie \& Keane, Mycosphaerella parva R.F. Park \& Keane, Mycosphaerella molleriana (Thüm.) Lindau, Mycosphaerella madeira Crous \& Denman, Mycosphaerella readeriellophora Crous \& J.P. Mansilla, Mycosphaerella communis Crous \& J.P. Mansilla, Mycosphaerella lateralis Crous \& M. J. Wingfield, and Mycosphaerella aurantia A. Maxwell have all been identified, although $90 \%$ corresponds to Mycosphaerella nubilosa [27].

Mycosphaerella nubilosa infects preferentially juvenile foliage, which explains the fact that the vast majority of trees showing symptoms of the disease are young or else young shoots with leaves, while trees with adult foliage are not damaged to such an extent. This is observed in other studies that have found the infection of MLD in young leaves of E. globulus $[16,24,28]$. Thus, it is the young stage of the species which is more relevant and on which this study is carried out.

In the literature, there are studies that show how to evaluate the severity of the disease $[15,24,29,30]$. This issue is of vital importance when managing industrial E. globulus stands since it could lead to failure. Eucalyptus globulus is a widely used species because of its potential as an energy crop in short rotations [31,32]. The management of MLD is especially important in this case, due to the short rotation length in which the young stage of this species predominates.

This article analyzes experimental Eucalyptus globulus stands in areas where MLD has high prevalence rates

The main objective of this study was to evaluate the impact of MLD on growth. Apart from this, other interesting points have been observed. The influence of fertilization in severity to MLD could offer an important information to forest managers in order to minimize the impact of MLD. It was also essential to check the impact of MLD in different origins, families, and subspecies. The other two issues that have been considered in this article were the influence of the type of foliage and the effect of clonal propagation. All this previous work could help to identify if there are families and individuals who present disease tolerance.

\section{Material and Methods}

Four trials or series were performed in 2004, 2007 (2), and 2010 (Table 1). The "seedlots" used in the trials have a range of provenances and subspecies within the natural range of E. globulus, as well as open-pollinated individual families, clones, and controlled-pollinated families. The seed from the Australian source, provided by CSIRO Forestry, belongs to three subspecies: E. globulus ssp. globulus, E. globulus ssp. Bicostata Maiden, and E. globulus ssp. Pseudoglobulus Naudin ex Maiden. Other provenances, open-pollinated individual families, clones, and controlled-pollinated families are local selections made by the Forest Research Center Bosques 2000 SL from natural forest in Northern Spain. The trials were planted in a completely randomized block design, with one plant 
material per block and 25 replicates. The planting framework was $2.5 \mathrm{~m} \times 2.5 \mathrm{~m}$. A temperature control-release fertilizer (formula 11-22-9+6 MgO) was added to the soil at a ratio of 20-30 g per plant at planting.

Table 1. Number of different types of taxa studied.

\begin{tabular}{ccccc}
\hline Year & Series 2004 & Series 2007 & Series 2007 & Series 2010 \\
\hline Forest Name & (Campos) & (Cabanzón) & (Arenal) & (La Cavada) \\
\hline Australian provenances & 50 & 17 & 28 & 11 \\
Other provenances & 60 & 31 & 21 & 11 \\
Open-pollinated individual families & 62 & 70 & 53 & 27 \\
Clones & 14 & 24 & 40 & 69 \\
Controlled-pollinated families & 0 & 10 & 25 & 31 \\
\hline
\end{tabular}

Site characteristics of each trial, including soil type and nutritional status, are provided in Table 2.

Table 2. Edaphic characteristics of the plots.

\begin{tabular}{ccccc}
\hline & \multicolumn{4}{c}{ Forest Name } \\
\cline { 2 - 5 } & Campos & Cabanzón & Arenal & La Cavada \\
\hline Sand (\%) & 8 & 35 & 27 & 31 \\
Alluvial (\%) & 42 & 31 & 29 & 40 \\
Clay (\%) & 48 & 28 & 44 & 23 \\
pH & 4.45 & 5.78 & 4.61 & 4.67 \\
Organic Matter (\%) & 1.1 & 4.5 & 2.4 & 3.4 \\
Phosphorus (mg/kg) & 0 & 1 & 0 & 1 \\
Calcium (mg/kg) & 147 & 1852 & 0 & 775 \\
Magnesium (mg/kg) & 66 & 105 & 0 & 72 \\
Potassium (mg/kg) & 78 & 45 & 43 & 103 \\
Type of soil & Alluvial-Clay & Mixed & Clay & Alluvial \\
\hline
\end{tabular}

For all trials, the severity of MLD in the whole crown was assessed based on disease assessment diagrams from references [29,30], whereby a branch was chosen at random and assessed for severity of affected leaf area based on disease assessment diagrams. This branch was used to represent severity over the whole juvenile crown. The intensity of defoliation was also assessed, based on the proportion of juvenile crown defoliation. A Crown Damage Index (CDI) was then calculated (Equation (1)), which combined the amount of foliage defoliated with the amount of leaf area damaged on leaves (i.e., MLD severity).

$$
\text { Crown Damage Index }(C D I \%)=\% \text { defoliation }+\frac{\% \text { severity }(100-\% \text { defoliation })}{100}
$$

Diameter at Breast Height over Bark (DBHOB) and height were measured at different ages, and height was measured at the adult-juvenile crown transition zone (Table 3). Percentage of adult crown was calculated based on the ratio between total height of tree and height of adult crown. Volume over bark was calculated using the volume equations developed by reference [33].

The percentage of adult leaf is estimated by the ratio between the height where adult leaf is found and the total height of the tree.

$$
\% \text { Mature foliage }=\frac{\text { Total height }- \text { Change foliage height }}{\text { Total height }} \times 100
$$


Table 3. Age to which the severity, change of foliage, height, and volume, were measured (months).

\begin{tabular}{ccccc}
\hline \multirow{2}{*}{ Variable Evaluated } & Series 2004 & Series 2007 & Series 2007 & Series 2010 \\
\cline { 2 - 5 } & Campos & Cabanzón & Arenal & La Cavada \\
\hline Severity & 18 & 25 & 21 & 25 \\
Change foliage height & - & 26 & 27 & - \\
Height & 39 & 27 & 27 & - \\
Volume & 39 & 2748 (clones) & - & - \\
\hline
\end{tabular}

Note: "-" stands for data not available.

Each series tested different plant material, except for a number of control codes that were repeated. These codes were plant material whose tolerance to MLD was better than its counterparts in previous series and about 20 codes of control families (which serve as a reference for comparison between different series). These control codes fall into three groups: (1) control families without any genetic improvement; (2) control codes improved with form and force criteria from open pollination; and (3) control codes from controlled crosses. None of these control families was selected with the criterion of tolerance to MLD. As the trials ran, the number of controlled crosses and clones of the best families, increased (Table 1).

\subsection{Trial 1: Campos Forest (2004 Series)}

The 2004 series is represented by the tests in Campos (210 m.a.s.1.) with an area of 2.5 ha. The plant material in this series was the genetic starting point. The starting plant material was considered sufficiently variable and representative for Eucalyptus globulus (Table 1). Only in this trial were subspecies of Eucalyptus globulus (globulus, pseudoglobulus and bicostata) incorporated. The objectives were:

- To analyze the evolution of MLD severity over a year in two zones (A and B) of approximately $1 \mathrm{ha}$, with different conditions in terms of topography, fog, sunshine, dew, and ventilation. Area A is located in the upper forest, with more natural ventilation, while Area B corresponds to a valley with more dew, fewer hours of sunshine, frequent accumulation of fog, and poor natural ventilation.

- To observe if there are significant differences in the severity of the MLD between subspecies of E globulus.

- To check the wood volume at 39 months, by category of disease severity for seedlings at 25 months of E. globulus.

\subsection{Trial 2: Cabanzón Forest (2007 Series)}

The 2007 series is represented by two tests: Cabanzón forest (220 m.a.s.l.) and Arenal forest (270 m.a.s.l.). This series incorporates new genetic material, material from the previous series and from the control families.

The objectives of the study performed in Cabanzón forest were four. First, the authors pretended to correlate the average MLD severity with the percentage of adult leaf. Another important point was to observe the change in average volume depending on severity categories. The relation of the Crown Damage Index (CDI) with other variables such as height, DBHOB and volume, was also matter of interest. Finally, the differences in volume between clones and seedlings will be analyzed.

\subsection{Trial 3: Arenal Forest (2007 Series)}

In Arenal forest the fundamental objective was to observe the effect of fertilization on MLD severity in families non-selected for their tolerance to MLD. In this trial, 12 months after planting, treatments with commercial fertilizers were used in order to favor the recovery of the plant after the attacks and to compare the evolution of MLD and growth to control (only fertilized at planting). 
Nine months after the treatment the severity of MLD was evaluated, in families from seed non-selected for their tolerance to MLD and 15 months after, height and percentage of mature foliage. The treatment followed these steps:

- the nitrogen treatments were the soluble complex N-P-K (15-15-15) at a ratio of $100 \mathrm{~g}$ per plant.

- the control-release fertilizer $(11-22-9+6 \mathrm{MgO})$ at a ratio of $30 \mathrm{~g}$ per plant.

- the treatment without any nitrogen (superphosphate $18 \% \mathrm{P}_{2} \mathrm{O}_{5}$ ) at a ratio of $150 \mathrm{~g}$ per plant.

\subsection{Trial 4: La Cavada Forest (2010 Series)}

The 2010 series is represented by a test located in La Cavada forest $(320 \mathrm{~m})$. This series incorporates new material plant tolerant from the disease. The objective was to compare between selected and non-selected material by their tolerance to MLD. Clones of both groups were also considered in this analysis. Clones obtained by own massal selection came from a selection whose main criterion was resistance to MLD. This selection was based on previous reforestation work performed in the region, on trees between 8 and 24 months, also taking into account shape and strength of trees. These trees were mobilized by grafting and cuttings.

The plant material selected for this series includes:

- MLD-tolerant families selected in previous series (Cabanzón forest (2007 series)).

- Families non-selected by their tolerance to MLD.

- Clones from one of these families (CI 105).

- Clones selected by external genetic testing (selected by form and force, not by their tolerance to MLD).

- Clones from own massal selection.

\subsection{Statistical Analysis}

In the statistical analysis, correlations between average severities of open-pollinated families were conducted in order to study the response to infection in the different trials. An analysis of variance (ANOVA) was also carried out in order to compare the severity averages [34]. Post hoc analysis for comparison of averages was undertaken using post hoc Tukey HSD test $(\alpha=0.05)$. The percentage data were treated using arc-sine square root transformation prior to analyses, in order to stabilize the variance error [35]. In the forest Cabanzón, the volume vs. CDI and adult leaves percentage vs. severity, were adjusted with linear and nonlinear equations, respectively. All tests were performed using IBM SPSS 21.0 statistical software program (SPSS Inc, Chicago IL, USA).

\section{Results}

\subsection{Campos Forest}

Figure 1 shows MLD severity over a year in two areas in the Campos forest. Severities above 70\% are found in area B of the forest during autumn and winter, while in area A the severity was lower than $50 \%$ during the same months. Although both areas belong to the same forest, they showed different MLD severity, 30\% in autumn-winter. In both areas, during the months between May and September the MLD severity is lower and the difference between the severities of area A and area B was very low. 


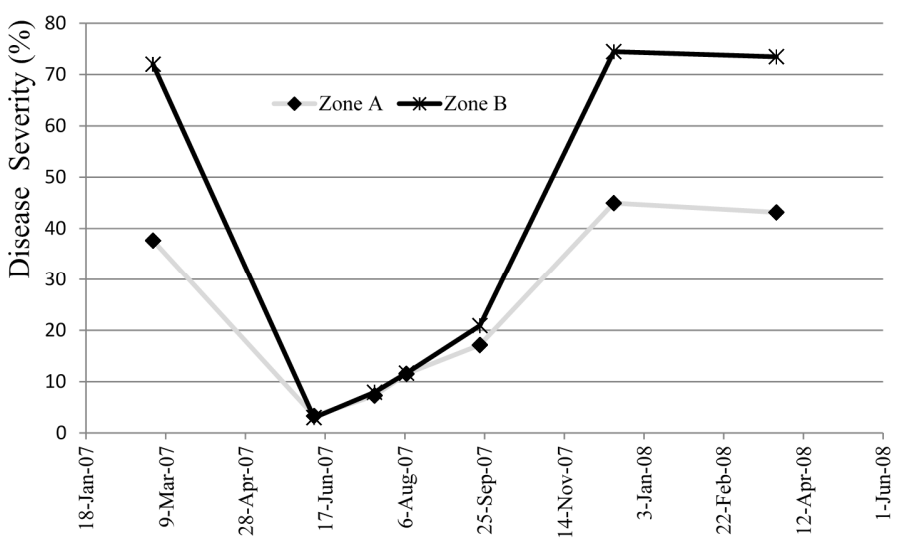

Figure 1. Evolution of the disease severity between March 2007 and March 2008, in two areas of the same Campos forest.

A negative correlation exists $(r=0.57, p<0.0001)$ between the average individual volume at 39 months of age and average individual severity at 18 months for seedlings. Table 4 shows the volume at 39 months according to category of disease severity. The disease severity has a significant effect on the volume reached by the seedlings at 39 months of age, if this is greater than $6 \%$. Below this severity value, volume differences are not significant. This suggests that those individuals more tolerant do not suffer significant damage from MLD.

Table 4. Individual tree volume at 39 months according to category of severity (Campos forest).

\begin{tabular}{cccc}
\hline Severity (\%) & Number of Trees & Individual Average Volume $\mathbf{( d m}^{\mathbf{3}}$ ) & Std. Error \\
\hline 3 & 148 & $15.89(\mathrm{a})$ & 2.89 \\
6 & 97 & $15.23(\mathrm{a})$ & 0.25 \\
12 & 954 & $10.25(\mathrm{~b})$ & 0.14 \\
25 & 1953 & $7.43(\mathrm{c})$ & 0.24
\end{tabular}

Means with the same letter following are not significantly different; Separations of means determined using post hoc Tukey HSD test $(\alpha=0.05)$.

One way ANOVA revealed significant differences ( $p$-value $<0.001)$ between average volume at 39 months and disease severity categories. Multiple comparison techniques indicated no significant differences in average volume for severities below $6 \%$. Severities of $12 \%$ and $25 \%$ involved a very significant effect on volume at 39 months.

ANOVA revealed significant differences ( $p$-value $<0.001$ ) between subspecies of E. globulus in terms of severity. Post hoc Tukey HSD shows that the three subspecies are significantly different from each other $(\alpha<0.05)$. Thus, the E. globulus ssp. pseudoglobulus from Cann River (VIC) shows severities lower than $7 \%$ while subspecies E. globulus ssp. bicostata and E. globulus spp. globulus show severities of $13 \%$ and $9 \%$ respectively (Figure 2 ).

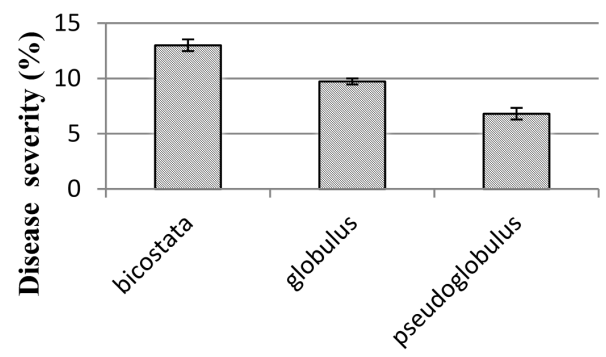

Figure 2. Average severity to Mycosphaerella Leaf Disease (MLD) of three subspecies of E. globulus in Campos forest. 


\subsection{Forest Cabanzon}

There was a negative correlation $\left(r^{2}=0.664, p<0.0001\right)$ between the average percentage of adult leaf at 27 months of age and the average disease severity of families at 25 months in the Cabanzón forest, such that trees with a higher proportion of adult foliage had lower disease than those with a higher proportion of juvenile foliage (Figure 3).

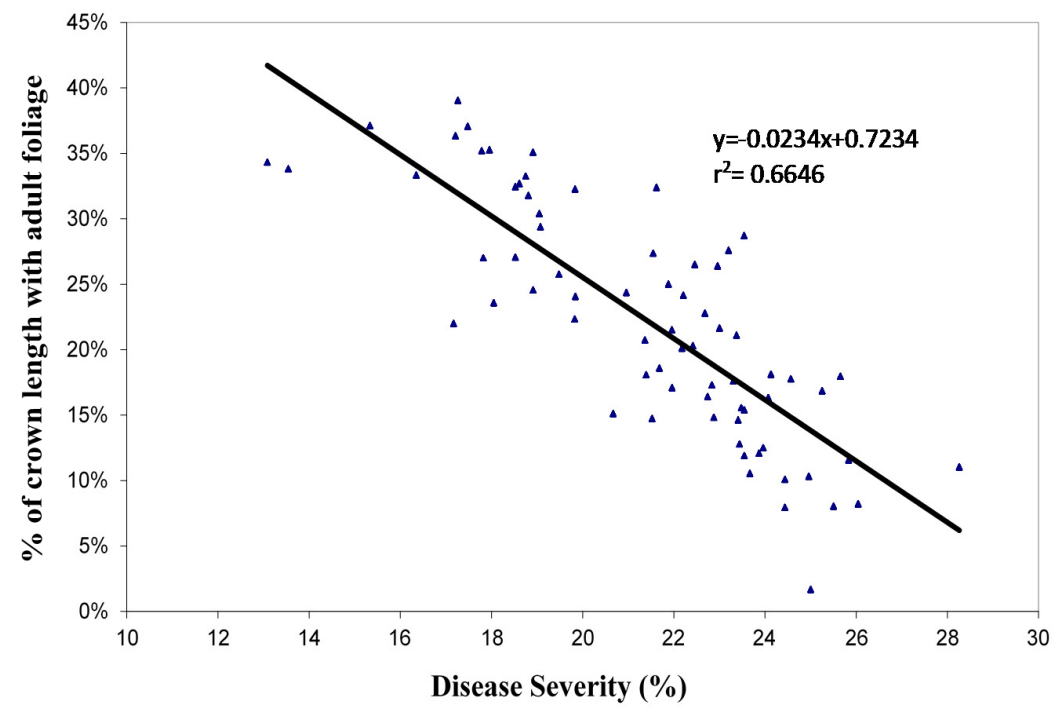

Figure 3. Correlation between average MLD severity at 25 months and the proportion of adult leaf (Cabanzón forest).

Table 5 shows the difference between MLD severity between families, varying from $50 \%$ to $3 \%$. Severities of $3 \%, 12 \%, 25 \%$, and 50\% measured at 25 months of age have a significant effect $(p<0.0001)$ on the volume measured at 27 months. ANOVA revealed significant differences between the volume measured at 27 months and the severity categories at 25 months. Post hoc tests (Tukey's test) show no significant differences in average volume for severity categories below $6 \%$.

Table 5. Average volume at 27 months versus severity at 25 months (Cabanzón forest).

\begin{tabular}{cccc}
\hline Severity (\%) & Number of Trees & Individual Average Volume $\mathbf{( d m}^{\mathbf{3}}$ ) & Std. Error \\
\hline 3 & 159 & $13.5(\mathrm{a})$ & 0.487 \\
6 & 78 & $12.9(\mathrm{a})$ & 0.650 \\
12 & 270 & $11.1(\mathrm{~b})$ & 0.322 \\
25 & 1628 & $8.5(\mathrm{c})$ & 0.093 \\
50 & 32 & $5.2(\mathrm{~d})$ & 0.527 \\
\hline
\end{tabular}

Means with the same letter following are not significantly different $(\alpha=0.05)$; Separations of means determined by post hoc Tukey HSD test $(\alpha=0.05)$.

Figure 4 shows the average height, DBHOB and volume grouped according to CDI categories. Post hoc analysis (Tukey HSD) indicated no significant differences between heights for CDI categories at 25 months which range from $55 \%$ to $70 \%$. The volume differences at 27 months for different categories of damage are significant $(p=0.281)$ (Figure 5$)$. There is a negative correlation $\left(r^{2}=0.98, p<0.01\right)$ between volume at 27 months and CDI measured at 25 months. Volumes decreased significantly while CDI increased. If CDI categories are grouped, three significantly different groups regarding the volume reached at 25 months can be observed (Figure 4). The volume reduction increases when CDI increases, suggesting that families with CDI above 55\% should be discarded in places with prevalence of MLD. 
With these data, new Eucalyptus globulus stands should be based on individuals that present a certain tolerance to MLD.

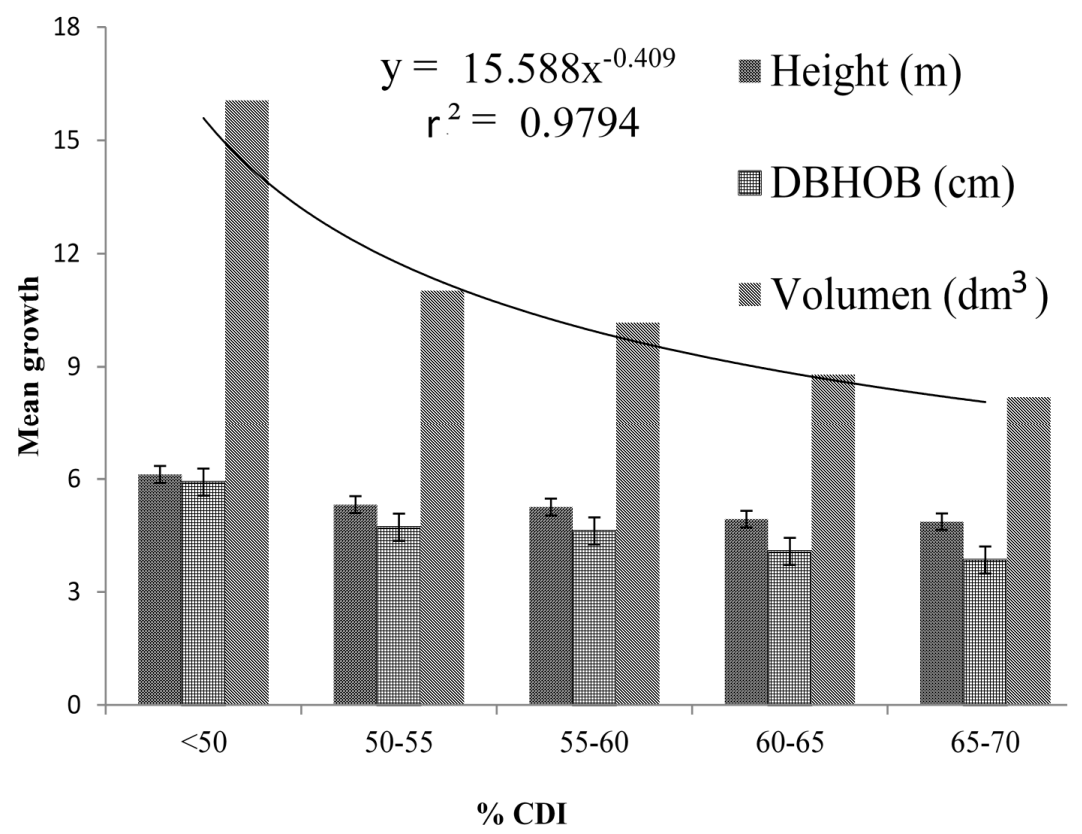

Figure 4. Average height, diameter and volume versus the Crown Damage Index (CDI) (seedlings in Cabanzón forest); Means with the same letter following are not significantly different $(\alpha=0.05)$.

Figure 5 presents the average volume at the age of four years of plants from seedlings and clones. ANOVA indicates significant differences $(p<0.0001)$ between cuttings volume and seedlings at four years of age. There are differences between volume in mature cuttings and seedlings of around $35 \%$. Tukey's test indicated no significant differences $(p<0.452)$ in the volume of non-mature cuttings (clones 146, and 115) and seedlings (Figure 5). In this point cuttings of juvenile (clone 146 and 115) and adult (clone 275, 110, and 28) material were considered.

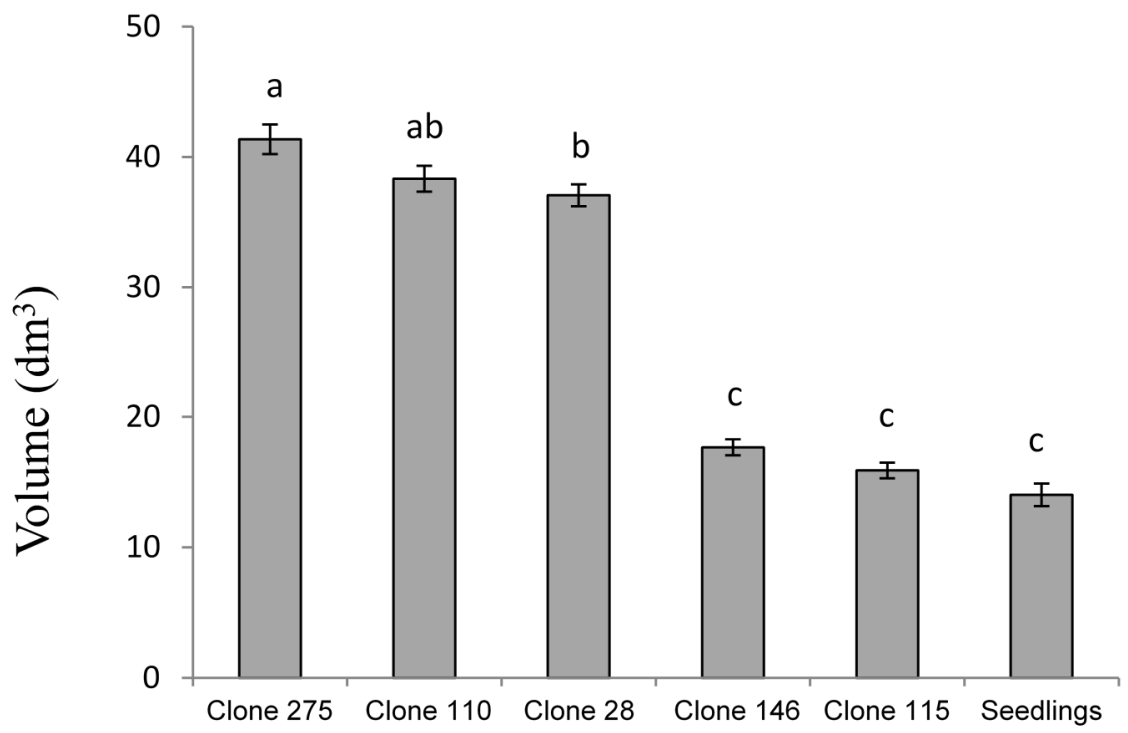

Figure 5. Average volume of several clones and seedlings at four years of age (Cabanzón forest); Means with the same letter following are not significantly different; Separation of means determined using post hoc Tukey HSD test $(\alpha=0.05)$. 


\subsection{Arenal Forest}

Table 6 shows the results of the fertilization treatments used in the Arenal Forest. Fifteen months after the application of the treatments, based on soluble nitrogen, significant improvement in growth is found $(p<0.0001)$. Otherwise, the treatments with controlled release or without any nitrogen also showed lower severities to MLD than the control, nine months after the application (severity difference with respect to control $11 \%$ and $8 \%$ respectively, p-value between 0.028 and 0.0077 ). The use of fertilizer improves the response with regard to control for the three variables $(p<0.0001)$. No significant differences in severities and heights are shown between treatments with NPK (15-15-15) soluble and controlled release fertilizer $(p<0.001)$. On the other hand, there are significant differences in the percentage of adult foliage. The presence of nitrogen has a positive effect on height and severity as far as phosphorus fertilization is concerned.

Table 6. Average severity ( 21 months), height, and adult foliage ( 27 months) percentage in families from seed non-selected for its tolerance to MLD with various fertilizers (Arenal forest).

\begin{tabular}{ccccccc}
\hline Treatment Fertilization & Severity (\%) & Std. Error & Height (m) & Std. Error & Adult Foliage (\%) & Std. Error \\
\hline 15-15-15 (soluble NPK) & $25.1(\mathrm{a})$ & 2.45 & $4.6(\mathrm{a})$ & 0.23 & $11(\mathrm{~b})$ & 2.92 \\
11-22-9+6 MgO & $28.2(\mathrm{a})$ & 2.41 & $4.53(\mathrm{a})$ & 0.22 & $8(\mathrm{~b})$ & 1.86 \\
(Controlled release) & $30.8(\mathrm{~b})$ & 1.86 & $3.11(\mathrm{~b})$ & 0.101 & 5 (c) & 0.67 \\
Superphosphate & $39.4(\mathrm{c})$ & 2.37 & $2.30(\mathrm{c})$ & 0.091 & 0 (d) & 0.025 \\
\hline Control &
\end{tabular}

Means with the same letter following are not significantly different $(\alpha=0.05)$; Separations of means determined by post hoc Tukey HSD test $(\alpha=0.05)$.

\subsection{La Cavada Forest}

Table 7 shows the results for the La Cavada forest (2007 Series), in terms of severity percentage, for plants that were non-selected and selected by their tolerance to MLD. There are significant differences among plant material non-selected and selected by their tolerance to MLD $(p<0.0001)$. Also, there is a significant effect on the cloning of adult trees favored by the early change to adult leaf (severity 19\%) compared to families from seed non-selected by its tolerance to MLD (severity 33.8\%). However, this effect is much lower than that achieved with the selection of tolerant families in genetic testing (severity 6.3\%). There is no significant difference in the severity $(p<0.646)$ between a family selected for its tolerance to MLD and the clones of the same family. The clones (C.I. 105) present very low severities: around $1.2 \%$.

No differences appear in severity between different types of seedlings not selected for their tolerance to the disease $(p<0.605)$ and non-mature cuttings not selected for their tolerance.

Table 7. Severity percentage at 25 months of MLD among families from seed non-selected and selected by its tolerance to MLD and their clones (La Cavada (2007 series)).

\begin{tabular}{ccccc}
\hline & & $\begin{array}{c}\text { Number } \\
\text { of Trees }\end{array}$ & $\begin{array}{c}\text { Mean Severity } \\
\text { (\%) }\end{array}$ & $\begin{array}{c}\text { Standard } \\
\text { Error }\end{array}$ \\
\hline \multirow{2}{*}{$\begin{array}{c}\text { Material non-selected } \\
\text { by their tolerance }\end{array}$} & $\begin{array}{c}\text { Families from seed non-selected } \\
\text { by their tolerance to MLD }\end{array}$ & 1173 & $33.8(\mathrm{a})$ & 0.154 \\
\cline { 2 - 5 } & $\begin{array}{c}\text { Mature cuttings non-selected by } \\
\text { their tolerance to MLD }\end{array}$ & 381 & 18.9 (b) & 0.364 \\
\cline { 2 - 5 } & $\begin{array}{c}\text { Non-mature cuttings non-selected } \\
\text { by their tolerance to MLD }\end{array}$ & 195 & 32.9 (a) & 0.246 \\
\hline \multirow{2}{*}{$\begin{array}{c}\text { Families from seed selected by } \\
\text { their tolerance to MLD }\end{array}$} & 520 & 6.3 (c) & 0.647 \\
\cline { 2 - 5 } their tolerance & Clone (CI 105) tolerant to MLD & 24 & $1.2(\mathrm{~d})$ & 0.185 \\
\cline { 2 - 5 } & Clones tolerant to MLD & 62 & $5.6(\mathrm{c})$ & 0.634 \\
\hline
\end{tabular}

Means with the same letter following are not significantly different $(\alpha=0.05)$; Separations of means determined by post hoc Tukey HSD test $(\alpha=0.05)$. 


\subsection{Correlation between Average Severities in Different Trials}

The response of families and provenances of E. globulus to the disease is fairly stable at the different sites. There are significant correlations in the average disease severity in families and provenances from the different tests. Table 8 shows the correlation matrix between trials at the Campos, Cabanzón, Arenal, and La Cavada stations. In order to correlate Arenal forest with other places, data from control blocks were used, i.e., only with fertilization at planting.

Table 8. Correlation matrix of average severity of Mycosphaerella sp. between trials of provenances and families.

\begin{tabular}{ccccccc}
\hline & \multicolumn{2}{c}{ Cabanzón } & \multicolumn{2}{c}{ Arenal } & \multicolumn{2}{c}{ La Cavada } \\
\cline { 2 - 7 } & $\boldsymbol{r}$ & $\boldsymbol{p}$-Value & $\boldsymbol{r}$ & $\boldsymbol{p}$-Value & $\boldsymbol{r}$ & $\boldsymbol{p}$-Value \\
\hline Campos & 0.623 & 0.003 & 0.52 & 0.005 & 0.53 & 0.100 \\
Cabanzón & & & 0.57 & 0.0002 & 0.605 & 0.0036 \\
Arenal & & & & & 0.487 & 0.0590 \\
\hline
\end{tabular}

\section{Discussion}

In all trials, there was a similarity between the families and provenances that tolerate the disease better. For the same material plant, a severity correlation of $r=0.95$ was found between two different places [36]. Similar results were described in reference [37], with correlation between 0.98 and 0.95 . These high correlations were possible because the trials were close and started at the same time and with the same plant material. In this study, although the correlation between sites is lower, this is positive and significant. This correlation indicates that tolerance to the disease is linked to genetic factors, and that families are tolerant regardless of the place. This genetic variation on the tolerance to MLD was also observed by other authors $[15,38]$. This indicates that the same selection of resistant genotypes on one site can be used at other sites.

Some studies relate the virulence of the MLD with rainy summers with high relative moisture [16,22]. Genotypes originating in areas with prevailing warm temperatures and high humidity have greater MLD tolerance than those originating in drier and cooler places $[29,30,38]$. A highly significant negative correlation between MLD damage and altitude was found by Jordan et al. [39]. In studies performed in Australia [30] showing MLD severity throughout the year it can be observed that the MLD impact is lower in winter than in summer. The results of this study show the opposite: it is specifically in summer that the severity is low. This may be due to the fact that because in Northern Spain during autumn and winter the combination of mild temperatures with frequent rainfall favors the development of MLD. The opposite is the case in summer, when higher temperatures and low rainfall reduce the development of MLD. The fact that there are great variations in terms of disease severity among stands in different microclimates (ventilation conditions, mist, duration of foggy periods, dew, etc.), is shown in Figure 1 for one year. Area A of the trial is less affected, recovering the spring following the attack, with the leaf changing to adulthood. In area B, with less ventilation and high accumulation of mist, the attack is very strong. This area does not recover after the attack, with most of the trees affected dying during the second year.

No significant differences can be observed between both areas in severity from May to October. During autumn and winter the severity of the disease reached the maximum annual in area B. These results corroborate the fact that small variations in microclimate variables, such as exposure to prevailing winds, altitude, relief, etc. are sufficient to produce significant oscillations in MLD incidence between areas close to each other.

Reductions in Eucalyptus nitens volume have been reported when more than $25 \%$ of the juvenile crown is defoliated [29]; below this value the tree would have a similar response to that of trees not infected by MLD (response type 1). 
Several studies describe differences between provenances of E. globulus mainly associated with the subspecies $[11,30,38]$. In Campos forest the three provenances of E. globulus ssp. bicostata were the most affected (Figure 2). The eight remaining origins of the subspecies E. globulus spp. globulus show intermediate severity with no significant differences between them. E. globulus spp. pseudo globulus showed the lowest severity. Our results are similar to those obtained by reference [30] and different from reference [38] where the subspecies bicostata had the lowest disease severity in juvenile foliage. These differences may be explained by the fact that provenances with rainy summers may have more natural resistance to MLD.

MLD mainly affects juvenile foliage [16]. There is genetic variation among individuals regarding height of transition from juvenile to adult leaves [40,41]. The heritability of the age at which leaf changes and its influence on MLD tolerance has been studied by Dungey et al. [36]. In Cabanzón forest, the severity measured at 25 months of age was lower for those families with higher proportion of adult leaf (Figure 3). This could be a way to select those families that show leaf change at younger ages, since they would be more tolerant of MLD. This hypothesis was presented by Freeman et al. [41] and could be valid for areas with a high prevalence of MLD. However, it would be necessary to check whether the age of phase change affects the volume of the tree at a certain age. The observations made by the authors conclude that the families of trees that are first to change from young to adult stage generate lower volumes than their congeners, at the same age. In Cabanzón forest the disease incidence was very high. Similarly, in Campos forest, there were no significant differences in the volume measured at 27 months among families with severities below $6 \%$ at 25 months (Table 4). Those families most susceptible to the disease (50\% severity) show volume reductions. In Cabanzón forest, (September 2009) levels of defoliation are very high: 60.6\%, which is much higher than previously described-34\% [15]. Volume losses of $64 \%$ in E. nitens have been associated with defoliation levels between $63 \%-75 \%$ [29]. This value is similar to that found in this study for E. globulus $(61.5 \%)$ for a CDI equal to $60.6 \%$.This loss of growth is not recovered over the life of the tree [42].

The clones from adult trees present a premature change from young to adult leaf (Figure 5). This feature makes these trees less sensitive to MLD so that the average severity for adult clones is lower than for seedlings. This lower sensitivity to MLD results in a lower loss of growth and, so, the clonal stands seem to offer a possible solution. In our experiment, the clones with high genetic value for growth, planted in areas with high prevalence of MLD and with an age of leaf change similar to that of seedlings show a growth loss similar to these (Figure 5: clone 146, clone 115). This shows that the cloning of a tree itself does not increase its tolerance to MLD and that the clones that do not have a premature leaf change do not present better growth in areas where there is high prevalence of MLD. As in other studies [38], in the stands of this work the infection occurred mainly during the second year, so strategies to advance leaf exchange seemed to mitigate the effects of MLD.

The fertility level of soil is a key factor in recovery after attack [42]. Nutritional requirements change with the age of the tree; for instance, in younger age groups the need for nitrogen is higher. According to reference [43], a N/P ratio around 10 seems to be stable in the first three years of life. The concentration of $\mathrm{N}$ in leaves is four times higher than in the trunk. This requirement may increase as there is a loss of leaf mass caused by the disease, and may also explain the differences in volume found in most fertilized stands. With the aim of reducing the juvenile stage of the species and achieving recovery of the plant after the attack, fertilization programs were used (Table 6). The change from young to adult leaf in E. globulus is under strong genetic control [41]. The environment influences the transition to adult foliage in E. nitens [44]. There is an environmental component that influences the transition from juvenile to adult leaf in E. globulus [45]. Nitrogen treatments help to reduce this transition while phosphorus has no influence. The application of phosphorus to $E$. nitens promoted leaf change in two places [44]. Levels of phosphorous were correlated with increased susceptibility of E. globulus to infection by Mycosphaerella cryptica in a 6-year-old fertilizer trial [46]. There is no unanimity among the authors, indicating that more experiments should be performed to better understand the role played by fertilization in the change to adult foliage. In our tests, the use of phosphorous decreased 
the severity $8 \%$ with regard to control (Table 6). The proportion of crown length in adult foliage is increased by applications of nitrogen [47]. In Arenal forest, fertilization treatments with NPK showed fewer severities, higher growth, and higher percentage of mature leaf than the reference at 27 months of age. In most of the trials, as the percentage of mature leaf increased the recovery was more remarkable. At present, stands are beginning to be seen where the infection is advanced and starts during the first year of life, so this strategy based on reducing the juvenile stage with fertilization is less effective. This coincides with reference [28], where it was noted that the MLD incidence was higher during the second year. The application of nitrogen fertilization in Arenal forest after heavy defoliation caused by MLD may have led to tree instability due to the size of the crown regenerated. This showed that nitrogen fertilization must be provided before defoliation starts. This fact was already observed in other places [15,47]. Fertilization benefits are not enough to dampen the damage caused by MLD on growth of young plantations of E. globulus. Severities where less than $10 \%$ of leaf is affected have negative effects on growth of young plantations of E. globulus [48]. This study shows that severities lower than $6 \%$ do not significantly affect the volume at 39 months of age (Tables 4 and 5). In Arenal forest, severity in the three scenarios is above $25 \%$, so fertilization helps to reduce the damage caused by MLD, but is far from a definitive tool.

Resistence to Mycosphaerella is highly heritable, meaning that the deployment of resistant genotypes is a management option in the long term [15] for producing healthier plantations. The selections that do not consider tolerance to the disease confer only vigor but no greater tolerance to MLD (Table 7: non mature cuttings, severity 32.9\%). The greater tolerance of mature cuttings due to early change to adult leaf is sometimes not enough in places with high prevalence. In La Cavada forest the families selected for their tolerance to MLD have lower severities than adult cuttings with premature leaf change (Table 7). These families obtained from seed selected by their tolerance presented severities of around $6.3 \%$ at 25 months, significantly lower than the non-tolerant plant material (seedlings and clones). The average severity of seedlings from these families was not significantly different from that of their clones. This again proves that cloning has no effect on resistance to MLD. Between these families, there is enough variability to find individuals that are exceptionally resistant to MLD (Table 8, clone CI 105). These individuals present average severities of around $1.2 \%$, i.e., they suffer practically no damage in areas of high prevalence of the disease. From our point of view, the way forward must be in the direction of the reproduction of individuals exceptionally tolerant to MLD. This reproduction can be through cloning or through controlled crossing between them. This is, like resistance to MLD, another extremely rare feature under strong genetic control.

\section{Conclusions}

The families and provenances that tolerate the disease better were the same in the different trials. Exposure to prevailing winds, altitude or relief are sufficient to produce significant oscillations in MLD incidence between areas close to each other. The subspecies E. globulus spp. bicostata had the lowest disease severity in juvenile foliage compared to E. globulus spp. globulus and E. globulus spp. pseudoglobulus. Fertilization benefits were not enough to dampen the damage caused by MLD on growth of young plantations of E. globulus. Resistence to Mycosphaerella is highly heritable, meaning that the deployment of resistant genotypes is a management option in the long term for producing healthier plantations. The use of mature cuttings can reduce the impact of MLD and provide homogeneity. However this characteristic does not guarantee a suitable growth in high disease prevalence areas. There is enough variability to find individuals that are exceptionally resistant to MLD. These individuals present average severities of around $1.2 \%$, i.e., they suffer practically no damage in areas of high prevalence of the disease.

The homogeneity of clonal plantations added to the resistance of these individuals would result in a greater volume of wood per hectare at a certain age. In return, the cost of production of these individuals versus conventional plant is higher. This work shows that genetic improvement is the best tool to fight in places of high MLD prevalence. Future developments should focus on obtaining 
seeds from controlled crosses of families and from clones that are tolerant to MLD. These seeds would be the basis for future generations of material plant resistance. In this process, it would be necessary to dispose of the maximum genetic variability in order to minimize the sensitivity to other pests (drought, frost or mushrooms).

Author Contributions: Severiano Perez was responsible for the design and coordination of the studies. Carlos Renedo, Alfredo Ortiz and Felix Ortiz participated in the analysis of results and drafting of the final conclusions for the four studied forests. Finally, Carlos Tejedor was the responsible of field work in all the forests.

Conflicts of Interest: The authors declare no conflict of interest.

\section{References}

1. Run, P.W.; Daping, X. Eucalyptus plantations. Research, management and development. In Proceedings of the International Symposium, Guangzhou, China, 1-6 September 2002.

2. Eldridge, K.; Davidson, J.; Harwood, C.; Van Wyk, G. Eucalypt Domestication and Breeding; Clarendon: Oxford, UK, 1993.

3. Potts, B.M.; Milgate, A.; Joyce, K.; Mohammed, C.L.; Vaillancourt, R.E.; Dutkowski, G.W. Quantitative genetic control of Mycosphaerella resistance in Eucalyptus globulus and impact on growth. In Proceedings of the IUFRO Conference Eucalyptus in a Changing World, Aveiro, Portugal, 11-15 October 2004.

4. Tibbits, W.N. Eucalypt plantations in Tasmania. Aust. For. 1986, 49, 219-225. [CrossRef]

5. Dutkowski, G.; Potts, B.M. Geogaphical patterns of genetic variation in Eucalyptus globulus ssp. globulus and a revised racial classification. Aust. J. Bot. 1999, 47, 237-263.

6. FAO Forestry Series 11. Eucalyptus for planting. 1981. Available online: http://www.fao.org/3/a-ac459e.pdf (accessed on 25 August 2016).

7. Borralho, N.M.G.; Cotterill, P.P.; Kanowski, P.J. Breeding objectives for pulp production of Eucalyptus globulus under different industrial cost structures. Can. J. For. Res. 1993, 23, 648-656. [CrossRef]

8. Greaves, B.L.; Borralho, N.; Raymond, C.A. Breeding objective for plantation eucalypts grown for production of kraft pulp. For. Sci. 1997, 43, 465-472.

9. Raymond, C.A.; Apiolaza, L.A. Incorporating wood quality and deployment traits in Eucalyptus globulus and Eucalyptus nitens. In Plantation Forest Biotechnology for the 21st Century; Walter, C., Carson, M., Eds.; Forest Research New Zealand: Rotorua, New Zealand, 2004; pp. 87-99.

10. Mohammed, C.; Wardlaw, T.; Smith, A.; Pinkard, E.; Battaglia, M.; Glen, M.; Tommerup, I.; Potts, B.; Vaillancourt, R. Mycosphaerella Leaf Diseases of Temperate Eucalypts Around The Southern Pacific Rim. N. Z. J. For. Sci. 2003, 33, 362-372.

11. Park, R.F.; Keane, P.J.; Wingfield, M.J.; Crous, P.W. Fungal disease of eucalypt foliage. In Diseases and Pathogens of Eucalypts; Keane, P.J., Kile, G.A., Podger, F.D., Brown, B.N., Eds.; CSIRO Publishers: Melbourne, Australia, 2000; pp. 153-239.

12. Crous, P.W.; Braun, U.; Groenewald, J.Z. Mycosphaerella is polyphyletic. Stud. Mycol. 2007, 58, 1-32. [CrossRef] [PubMed]

13. Crous, P.W. Mycosphaerella sp. and their anamorphs associated with leaf spot diseases of Eucalyptus. In Mycological Memoir 21; APS Press: St. Paul, MN, USA, 1998; p. 170.

14. Crous, P.W.; Hong, L.; Wingfield, B.D.; Wingfield, M.J. Its rDNA phylogeny of selected Mycosphaerella species and their anamorphs ocurring on Myrtaceae. Mycol. Res. 2001, 105, 425-431. [CrossRef]

15. Milgate, A.W.; Potts, B.M.; Joyce, K.; Mohammed, C.; Vaillancourt, R.E. Genetic variation in Eucalyptus globulus for susceptibility to Mycosphaerella nubilosa and its association with tree growth. Aust. Plant Path. 2005, 34, 11-18. [CrossRef]

16. Park, R.F.; Keane, P.J. Three Mycosphaerella species from leaf diseases of Eucalyptus. Trans. Br. Mycol. Soc. 1982, 79, 95-100. [CrossRef]

17. Pérez, G.; Hunter, G.; Slippers, B.; Pérez, C.; Wingfield, B.; Wingfield, M. Teratosphaeria (Mycosphaerella) nubilosa, the causal agent of Mycosphaerella leaf disease (MLD), recently introduced into Uruguay. Eur. J. Plant Pathol. 2009, 125, 109-118. [CrossRef]

18. Ahumada, R. Pathogens in Commercial Eucalyptus Plantations in Chile, with Special Reference to Mycosphaerella and Botryosphaeria Species. Master's Thesis, University of Pretoria, Pretoria, South Africa, 2003. 
19. Smith, A.; Pinkard, E.; Stone, C.; Battaglia, M.; Mohammed, C. Precision and accuracy of pest and pathogen damage assessment in young eucalypt plantations. Environ. Monit. Assess. 2005, 111, 243-256. [CrossRef] [PubMed]

20. Hunter, G.C.; Roux, J.; Wingfield, B.D.; Crous, P.W. Mycosphaerella species causing leaf disease in South African Eucalyptus plantations. Mycol. Res. 2004, 108, 672-681. [CrossRef] [PubMed]

21. Silva, M.; Valente, C.; Neves, L.; Machado, H. Mycosphaerella species occurring on Eucalyptus globulus in Portugal. Eur. J. Plant Pathol. 2009, 125, 425-433. [CrossRef]

22. Park, R.F. Epidemiology of Mycosphaerella nubilosa and M. cryptica on Eucalyptus spp. in South-eastern Australia. Trans. Br. Mycol. Soc. 1988, 91, 261-266. [CrossRef]

23. Milgate, A.W.; Yuan, Z.Q.; Vaillancourt, R.E.; Mohammed, C. Mycosphaerella species occurring on Eucalyptus globulus and Eucalyptus nitens plantations of Tasmania, Australia. For. Pathol. 2001, 31, 53-63. [CrossRef]

24. Carnegie, A.J.; Ades, P.K. The proportion of leaf spots caused by Mycosphaerella cryptica and M. nubilosa on Eucalyptus globulus, E. nitens and their F1 hybrids in a family trial in Tasmania, Australia. Aust. Mycol. 2002, 21, 53-63.

25. Jackson, S.L.; Maxwell, A.; Burgess, T.I.; Hardy, G.E.S.J.; Dell, B. Incidence and new records of Mycosphaerella species within a Eucalyptus globulus plantation in Western Australia. For. Ecol. Manag. 2008, 255, 3931-3937. [CrossRef]

26. Aguín, O.; Sainz, M.J.; Ares, A.; Otero, L.; Mansilla, J.P. Incidence, severity and causal fungal species of Mycosphaerella and Teratosphaeria disease in Eucalyptus globulus stands in Galicia (NW Spain). For. Ecol. Manag. 2013, 302, 379-389. [CrossRef]

27. Otero, L.; Aguín, O.; Saiz, M.J.; Mansilla, J.P. El género Mycosphaerella en plantaciones de Eucalyptus en Galicia. Bol. Sanid. Veg. 2007, 33, 503-516.

28. Maxwell, A. The Taxonomy Philogeny and Impact of Mycosphaerella Species on Eucalypts in South-Western Australia. Ph.D. Thesis, School of Biothecnology and Biological Science, Murdoch University, Murdoch, Australia, 2004.

29. Lundquist, J.E.; Purnell, R.C. Effects of Mycosphaerella Leaf spot on growth of Eucalyptus nitens. Plant Dis. 1987, 71, 1025-1029. [CrossRef]

30. Carnegie, A.J.; Keane, P.J.; Ades, P.K.; Smith, I.W. Variation in susceptibility of Eucalyptus globulus provenances to Mycosphaerella leaf disease. Can. J. For. Res. 1994, 24, 1751-1757. [CrossRef]

31. Pérez, S.; Renedo, C.J.; Ortiz, A.; Mañana, M.; Delgado, F.; Tejedor, C. Energetic density of different forest species of energy crops in Cantabria (Spain). Biomass Bioenergy 2011, 35, 4657-4664. [CrossRef]

32. Pérez, C.; Merino, A.; Rodriguez, R. A management tool for estimating bioenergy production and carbon sequestration in Eucalyptus globulus and Eucalyptus nitens grown as short rotation woody crops in north-west Spain. Biomass Bioenergy 2011, 35, 2839-2851. [CrossRef]

33. Pita, P.A. Tablas de Cubicación por Diámetros Normales y Alturas Totales; I.F.I.E. Ministerio de Agricultura: Madrid, Spain, 1967.

34. Sheskin, D.J. Handbook of Parametric and Nonparametric Statistical Procedures, 3rd ed.; Chapman \& Hall/CRC: Boca Raton, FL, USA, 2003.

35. Zar, J.H. Biostatistical Analysis, 3rd ed.; Prentice Hall International: Upper Saddle River, NJ, USA, 1996.

36. Dungey, H.S.; Potts, B.M.; Carnegie, A.J.; Ades, P.K. Mycosphaerella leaf disease: Genetic variation in damage to Eucalyptus nitens, Eucalyptus globulus, and their F1 hybrid. Can. J. For. Res. 1997, 27, 750-759. [CrossRef]

37. Carnegie, A.J.; Johnson, I.G.; Henson, M. Variation among provenances and families of blackbutt (Eucalyptus pilularis) in early growth and susceptibility to damage from leaf spot fungi. Can. J. For. Res. 2004, 34, 2314-2326. [CrossRef]

38. Jordan, G.J.; Potts, B.M.; Wiltshire, R.J.E. Strong, independent, quantitative genetic control of the timing of vegetative phase change and first flowering in Eucalyptus globulus ssp. globulus (Tasmanian Blue Gum). Heredity 2002, 83, 179-187. [CrossRef]

39. Jordan, G.J.; Potts, B.M.; Chalmers, P.; Wiltshire, R.J.E. Quantitative genetic evidence that the timing of vegetative phase change in Eucalyptus globulus ssp. globulus is an adaptive trait. Aust. J. Bot. 2000, 48, 561-567. [CrossRef]

40. Reinoso, C. Variation in Eucalyptus globulus in Susceptibility to Mycosphaerella Leaf Diseases. Master's Thesis, University of Melbourne, Melbourne, Australia, 1982. 
41. Freeman, J.S.; Potts, B.M.; Vaillancourt, R.E. Few mendelian genes underlie the quantitative response of a forest tree, Eucalyptus globulus, to a natural fungal. Genetics 2008, 178, 563-571. [CrossRef] [PubMed]

42. Smith, A. The Development of Strategies for the Management and Research of Foliar Pathogens on Eucalypt Plantations: Using Mycosphaerella as a Case Study. Master's Thesis, School of Agricultural Science, University of Tasmania, Hobart, Australia, 2006.

43. Suárez, D.; Bonomelli, C. Evolución de la demanda de N-P-K en los tres primeros años de crecimiento de E. nitens Maiden y E. globulus Labill en tres ecosistemas de la VIII Región de Chile. In Proceedings of the Simposio IUFRO, Valdivia, Chile, September 2001.

44. Williams, D.R.; Potts, B.M.; Smethurst, P.J. Phosphorus fertiliser caninduce earlier vegetative phase change in Eucalyptus nitens. Aust. J. Bot. 2004, 52, 1-4. [CrossRef]

45. Pinkard, E.A.; Baillie, C.C.; Patel, V.; Mohammed, C.L. Effects of fertilising with nitrogen and phosphorus on growth and crown condition of Eucalyptus globulus Labill. experiencing insect defoliation. For. Ecol. Manag. 2006, 231, 131-137. [CrossRef]

46. Carnegie, A.J.; Ades, P.K. Added phosphorus is associated with reduced severity of Mycosphaerella cryptica in Eucalyptus globulus. Aust. For. 2001, 64, 203-208. [CrossRef]

47. Pinkard, E.A.; Baillie, C.C.; Patel, V.; Paterson, S.; Battaglia, M.; Smethurst, P.J.; Mohammed, C.L.; Wardlaw, T.; Stone, C. Growth responses of Eucalyptus globulus Labill to nitrogen application and severity, pattern and frequency of artificial defoliation. For. Ecol. Manag. 2006, 229, 378-387. [CrossRef]

48. Carnegie, A.J.; Ades, P.K. Mycosphaerella leaf disease reduces growth of plantation-grown Eucalyptus globulus. Aust. For. 2003, 66, 113-119. [CrossRef]

(C) 2016 by the authors; licensee MDPI, Basel, Switzerland. This article is an open access article distributed under the terms and conditions of the Creative Commons Attribution (CC-BY) license (http://creativecommons.org/licenses/by/4.0/). 